Check for updates

Cite this: RSC Adv., 2017, 7, 36185

Received 13th June 2017 Accepted 14th July 2017

DOI: $10.1039 / \mathrm{c} 7 \mathrm{ra06580a}$

rsc.li/rsc-advances

\section{The in vivo anti-tumor effect of curcumin derivative (2E,6E)-2,6-bis(4-hydroxy-3-methoxybenzylidene) cyclohexanone (BHMC) on 4T1 breast cancer cells}

\author{
Nursyamirah Abd Razak, ${ }^{a}$ M. Nadeem Akhtar, ${ }^{b}$ Nadiah Abu, ${ }^{c}$ Wan Yong Ho, ${ }^{d}$ \\ Sheau Wei Tan, ${ }^{a}$ Seema Zareen, ${ }^{\text {b }}$ Saiful Nizam bin Taj-ud-din, ${ }^{\mathrm{b}}$ Kamariah Long, (D) \\ Noorjahan Banu Alitheen ${ }^{\star f}$ and Swee Keong Yeap (D) *ag
}

Curcumin is one of the promising natural products extracted from the rhizomes of curcuma longa and has been extensively investigated by researchers to explore its potential as a chemopreventive and therapeutic agent against several chronic diseases. To further enhance the cytotoxic potential of curcumin, its derivative (2E,6E)-2,6-bis(4-hydroxy-3-methoxybenzylidene)cyclohexanone (BHMC) has been synthesized and investigated, and its antitumor effect on tested on 4T1 challenged mice. BHMC was recorded with in vitro cytotoxicity on murine $4 \mathrm{~T} 1$ breast cancer cells with $\mathrm{IC}_{50}$ value $13.66 \mu \mathrm{M}$, which was 2 times lower than curcumin after 72 hours of treatment. An in vivo study indicated that BHMC possessed antitumor effect on the 4T1 cells of the challenged mice by induction of apoptosis, antiproliferation, antiinflammation and antimetastasis. This effect is better compared to curcumin treatment at the same evaluated concentration. Thus, BHMC is a potential antitumor agent against breast cancer.

\section{Introduction}

Cancer is still among the leading causes of death worldwide with breast cancer as the primary cancer incidence for women. ${ }^{1}$ Triple negative breast cancer (TNBC) is the subtype of breast cancer with absence of estrogen receptor, progesterone receptor and human epidermal growth factor receptor 2 (HER2). TNBC is highly aggressive associated with high event of relapse, metastasis and poor survival. Chemotherapy is the common strategy among the limited treatment options for TNBC. However, TNBC may possess resistance against standard chemotherapeutic drugs such as anthracycline and taxane if they have been previously used as adjuvant or neoadjuvant. Thus, there is

${ }^{a}$ Institute of Bioscience, Universiti Putra Malaysia, Serdang, Selangor, Malaysia. E-mail: skyeap2005@gmail.com; Tel: +60-3-88006901

${ }^{b}$ Bio-aromatic Research Center of Excellence, Faculty of Industrial Sciences \& Technology, Universiti Malaysia Pahang, Lebuhraya Tun Razak, Kuantan 26300, Pahang, Malaysia

'UKM Molecular Biology Institute (UMBI), UKM Medical Centre, Jalan Yaa'cob Latiff, Bandar Tun Razak, Cheras 56000, Kuala Lumpur, Malaysia

${ }^{a}$ School of Biomedical Sciences, The University of Nottingham Malaysia Campus, Jalan Broga, Semenyih 43500, Selangor, Malaysia

${ }^{e}$ Malaysian Agricultural Research and Development Institute (MARDI), Serdang, Selangor 43400, Malaysia

${ }^{f}$ Department of Cell and Molecular Biology, Faculty of Biotechnology and Biomolecular Sciences, Universiti Putra Malaysia, Serdang, Selangor 43400, Malaysia. E-mail: noorjahan@upm.edu.my

${ }^{g}$ China-ASEAN College of Marine Sciences, Xiamen University Malaysia, Jalan Sunsuria, Bandar Sunsuria, Sepang 43900, Selangor, Malaysia a need to discover potential treatment for TNBC. $^{2}$ Natural compound has been proposed as safe and potential agent against TNBC. ${ }^{3}$ Among the natural compounds, curcumin that present in the spice turmeric has been reported with antitumor effect on TNBC.,5 Resolving cancer challenged by natural product hold better potential with the introduction of chemical synthesis, which resolve the availability of the compounds of interest. ${ }^{6}$ On the other hand, synthetic compounds also help to improve the drug sensitivity and specificity while reduce the toxicity via chemical modification. ${ }^{7}$

Curcumin (Fig. 1A) is one of the classical natural product extracted from the rhizomes of Curcuma longa (turmeric) and named it curcumin. ${ }^{8}$ Curcumin mainly identified as

A.<smiles>COc1cc(C=C/C(O)=C/C(=O)/C=C/c2ccc(O)c(OC)c2)ccc1O</smiles>

B.

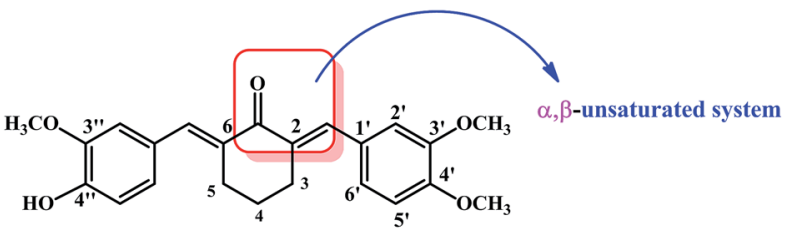

(2E,6E)-2,6-bis(4-hydroxy-3-methoxybenzylidene)cyclohexanone (BHMC)

Fig. 1 The chemical structures of (A) curcumin and (B) 2,6-bis-(4hydroxy-3-methoxybenzylidene)cyclohexanone (BHMC). 
antioxidant, anti-inflammatory, ${ }^{9-12}$ anti-cancer ${ }^{9,13-17}$ and antiacetylcholinesterase ${ }^{18}$ activities. Several biological activities including the hepato- and nephro-protective, ${ }^{19-22}$ thrombosis suppressing, ${ }^{23}$ myocardial infarction protective, ${ }^{24,25}$ curcumin has proved to be potential candidate for future drug discovery. In spite of several pharmacological properties, curcumin that was classified under "pans-assay interference compounds" and "invalid metabolic panaceas" still facing several liabilities including instability, poor solubility, poor selectivity and multiple modes of assay interference particularly to the in vitro based assays. ${ }^{26,27}$ Thus, more efforts to improve efficacy, selectivity of curcumin are needed. In recent years, chemical modification of curcuminoids has been increasingly investigated. For example, various curcumin analogues have been reported with enhance antitumor effect than curcumin. ${ }^{28} \mathrm{~A}$ curcumin derivative, 2,6-bis(4-hydroxy-3-methoxybenzylidene)cyclohexanone (BHMC) (Fig. 1B) has been synthesised with diketone moiety of curcumin has been replaced with mono cyclic ketone. To avoid false positive results contributed by the assay interference character of curcumin, in vivo validation are especially on those potential curcumin analog. ${ }^{27}$ This synthetic curcuminoid analogue has been reported with antinociceptive effect in mice through inhibition of various inflammatory mediators..$^{29-31}$ Inflammation has been correlated with progression of triple negative breast cancer including promotion of cancer cells invasion and migration. ${ }^{32}$ The anti-inflammatory effect of BHMC has been evaluated in vitro ${ }^{29}$ and in vivo. ${ }^{30}$ BHMC has been reported with cytotoxic effect on estrogen dependent MCF7 cells. ${ }^{33}$ In addition, BHMC was reported with greater in vitro cytotoxic effect than curcumin to TNBC MDA-MB-231 cells. ${ }^{34}$ However, the in vivo antitumor effect of BHMC particularly on TNBC was not evaluated. 4T1 has been reported as excellent model system for TNBC study as its physical location, proliferative, metastatic and inflammatory characteristics mimic human TNBC. ${ }^{32,35}$ In this study, 2,6-bis(4-hydroxy-3methoxybenzylidene)cyclohexanone (BHMC) was synthesized and its antitumor effect was compared with curcumin using in vivo $4 \mathrm{~T} 1$ mouse model.

\section{Materials and methods}

\subsection{Synthesis of BHMC}

Curcumin (C7727) was purchased from Sigma-Aldrich (USA). BHMC was chemically synthesized from 4-hydroxy-3methoxybenzaldehyde (cyclohexanone). Briefly, a mixture of 3methoxy-4-hydroxy (vanillin) (40 mmol, 2 equiv.) and cyclohexanone ( $20 \mathrm{mmol}, 1$ equiv.) was dissolved in $25 \mathrm{~mL}$ of absolute ethanol. The mixture was heated at $50{ }^{\circ} \mathrm{C}$ for half hour and conc. $\mathrm{HCl}(2.0 \mathrm{~mL})$ was added drop wise over $5 \mathrm{~min}$ to the stirred mixture. The mixture was further stirred for one hours and left over night in refrigerator. The mixture was dissolved in ice water $(500 \mathrm{~mL})$ and transferred into separating funnel. A yellow viscous product was floating on the surface of water, which was extracted with ethyl acetate $(250 \mathrm{~mL} \times 3$ times $)$. The ethyl acetate layer was collected, dried over rotary evaporator and then pass to sodium sulphate anhydrous. The crude product was subjected to further purification by silica gel column chromatography. The column was eluted with ethyl acetate and hexane $(40: 60 \%)$. Yield $76 \%$; yellow powder, $\mathrm{UV}\left(\mathrm{CHCI}_{3}\right): \lambda_{\max }$ 302, $339 \mathrm{~nm}$; IR $\left(\mathrm{CHCl}_{3} \mathrm{~cm}^{-1}\right): \nu_{\max } 3393(\mathrm{OH}), 2928(\mathrm{Ar}-\mathrm{C}-\mathrm{H})$ $1618(\mathrm{C}=\mathrm{O}), 1527$ (Ar C=C str.); ${ }^{1} \mathrm{H}-\mathrm{NMR}\left(600 \mathrm{MHz}, \mathrm{CDCI}_{3}\right)$ : $\delta$ in ppm: $7.78(\mathrm{bs}, 2 \mathrm{H},-\mathrm{C}=\mathrm{C}-\mathrm{H}), 7.12(\mathrm{dd}, 2 \mathrm{H}, J=8.34,1.92 \mathrm{~Hz}$, $\left.\mathrm{H}-6^{\prime}, \mathrm{H}-6^{\prime \prime}\right), 7.02\left(\mathrm{~d}, 2 \mathrm{H}, J=1.92 \mathrm{~Hz}, \mathrm{H}-2^{\prime}, \mathrm{H}-2^{\prime \prime}\right), 6.90(\mathrm{~d}, 2 \mathrm{H}, J=$ $\left.7.90 \mathrm{~Hz}, J=8.34, \mathrm{H}-5^{\prime}, \mathrm{H}-5^{\prime \prime}\right), 3.91\left(\mathrm{~s}, 6 \mathrm{H}, 2 \times \mathrm{OCH}_{3}, \mathrm{C}-3^{\prime}, \mathrm{C}-3^{\prime \prime}\right)$, $2.90(\mathrm{~m}, 4 \mathrm{H}, \mathrm{H}-3, \mathrm{H}-5), 1.82(\mathrm{~m}, 2 \mathrm{H}, \mathrm{H}-4) .{ }^{13} \mathrm{C}-\mathrm{NMR}(150 \mathrm{MHz}$, $\left.\mathrm{CDCI}_{3}\right) \delta$ in ppm: 190.41, (C=O), $151.89\left(\mathrm{C}-4^{\prime}, \mathrm{C}-4^{\prime \prime}\right), 149.71(\mathrm{C}-$ $\left.3^{\prime}, 3^{\prime \prime}\right), 136.83,(-\mathrm{C}=\mathrm{C}-\mathrm{H}), 134.80(\mathrm{C}-2,6), 132.23\left(\mathrm{C}-1^{\prime}, 1^{\prime \prime}\right)$ 128.36, (C-6', $\left.6^{\prime \prime}, 2^{\prime}, 2^{\prime \prime}\right), 115.34,\left(\mathrm{C}-5^{\prime}, 5^{\prime \prime}\right),\left(56.07, \mathrm{OCH}_{3}\right), 28.74$, (C-3, C-5), (23.42, C-4). MS: $m / z=366(100 \%)[\mathrm{M}]^{+}$, EI-MS $m / z$ (rel. int.) 351 (56), 335 (68). 321 (17), 309 (12), 161 (24), 131 (15). HR-EIMS $\mathrm{C}_{22} \mathrm{H}_{22} \mathrm{O}_{5}$. 366.231 calc. for 366.229.

The purity of compound was determined by using JASCOHPLC attached with ChromNAV-software (JASCO Corporation, Tokyo, Japan). The column used XBridge RP-18 ( $5 \mu \mathrm{m}$ particle size, $4.6 \times 150 \mathrm{~mm}$ i.d.; Waters Corporation, Wexford, Ireland) kept at ambient temperature. Injection volume of $20 \mu \mathrm{L}$, flow

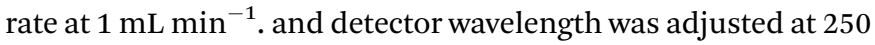
and $366 \mathrm{~nm}$, mobile phase $\mathrm{H}_{2} \mathrm{O}$ and $\mathrm{MeOH}(40: 60)$, retention time $\left(t_{\mathrm{R}}\right) 11.66 \mathrm{~min}$. The percentage of purity was determined by calculating the peak purity method automatically. ${ }^{36}$

\subsection{In vitro cell viability assay}

Murine 4T1 TNBC cells were purchased from American Type Culture Collection and cultured in RPMI-1640 medium (SigmaAldrich, USA) supplemented with 10\% Fetal Bovine Serum (FBS) (Gibco, Thermo Fisher Scientific, USA) at $37{ }^{\circ} \mathrm{C}, 5 \% \mathrm{CO}_{2}$. Cell viability was determined by MTT assay where $4 \mathrm{~T} 1$ cells were seeded $\left(0.8 \times 10^{5}\right.$ cells per $\left.\mathrm{mL}\right)$ in 96 well plate overnight. Then, BHMC and curcumin (Sigma-Aldrich, USA) were added to the cells at concentration ranging within $30-0.47 \mu \mathrm{g} \mathrm{mL} \mathrm{m}^{-1}$ by two fold serial dilution and further incubated at $37{ }^{\circ} \mathrm{C}, 5 \% \mathrm{CO}_{2}$ for 24,48 or 72 hours. After the incubation time, MTT solution (5 mg mL ${ }^{-1}$ ) was added into all wells and further incubated for 4 hours. The purple formazon formed was then dissolved by 100 $\mu \mathrm{L}$ of DMSO (Sigma-Aldrich, USA) and the absorbance was measured at $570 \mathrm{~nm}$ using $\mu$ Quant plate reader (Bio-Tek Instrument, USA). Cell viability was calculated as below:

Cell viability $(\%)=($ absorbance of treated well $) /$ (absorbance of control well) $\times 100 \%$

$\mathrm{IC}_{50}$ (concentration that reduce $50 \%$ of cell viability comparing to untreated cells) was obtained from the graph of cell viability $v s$. concentration.

\subsection{In vivo antitumor effect of BHMC}

Female mice ( $n=18,6$ weeks old) were purchased from Comparative Medicine and Technology Unit (COMeT), Institute of Bioscience, Universiti Putra Malaysia. The mice were fed with distilled water and standard pellets ad libitum at room temperature and 12 hours of day/dark light cycles. This study was conducted according to the guidelines and was approved by 
Institution of Animal Care and Use Committee (IACUC), Universiti Putra Malaysia (UPM/IACUC/AUP-R009/2015). All animal experiment was carried out in accordance with the Malaysia Animals Act 1953 (Revised-2006) under Malaysian Veterinary Council (MVC) for animal experiments.

After 2 weeks of acclimatization of mice (body weight $\sim 22 \mathrm{~g}$ ), mice were separated into 3 groups and challenged with $1 \times 10^{5}$ $4 \mathrm{~T} 1$ cells per mice subcutaneously. BHMC and curcumin were dissolved in olive oil. Untreated mice $(n=6)$ were fed with olive oil, curcumin 50 mice were orally fed with $50 \mathrm{mg} \mathrm{kg}^{-1}$ body weight (BW) of curcumin (Sigma-Aldrich, USA) and BHMC 50 mice were orally fed with $50 \mathrm{mg} \mathrm{kg}^{-1}$ BW of BHMC for 28 days. Throughout the experiment period, tumors were measured using a caliper and the tumor volumes were calculated by the following formula:

$$
\text { Tumor volume }=\left(d^{2} \times a\right) / 2
$$

$d=$ tumor measurement at the widest point $a=$ tumor dimension at the longest point.

After the 28 days of treatment, mice were amnestied with isoflurane, and euthanised by cervical dislocation. Serum, lung and tumor were collected and subjected to the following assays. Tumor per body weight ratio was calculated.

\subsection{Hematoxylin and eosin (H\&E) histology analysis of tumor}

Harvested tumor was fixed in $10 \%$ formalin, embedded in paraffin, section and stained with H\&E. Histology of the tumor was viewed under bright-field microscope (Nikon, Japan). Even of mitotic cells were counted from five random fields of the slides.

\subsection{Lung clonogenic assay}

Lung was harvested, washed with ice-cold PBS, minced, treated with $2 \mathrm{mg} \mathrm{mL} \mathrm{m}^{-1}$ collagenase type IV for 1 hour at $37{ }^{\circ} \mathrm{C}$ and filtered through $70 \mu \mathrm{m}$ strainer. Then, the filtrate was pelleted at $2000 \mathrm{rpm}$ for 5 minutes. The lung pellet was cultured in $10 \mathrm{~mL}$ of RPMI-1640 supplemented with 10\% Fetal Bovine Serum (FBS) (Gibco, Thermo Fisher Scientific, USA) at $37{ }^{\circ} \mathrm{C}, 5 \% \mathrm{CO}_{2}$ for 10 days. After the incubation period, all wells were fixed with methanol for 1 hour and stained with $0.5 \%$ crystal violet for 2 hours. Number of colonies formed per organ was counted for untreated, curcumin treated and BHMC treated groups.

\subsection{Expression of MMP9, TNF- $\alpha$, IL-1 $\beta$, IL-4, G-CSF and NF- $k B$ in tumor by quantitative reverse transcription PCR (RT- qPCR)}

Total RNA from the tumor was extracted using RNeasy mini kit (Qiagen, USA) according to the manufacturer's protocol. cDNA was synthesized from $1 \mu \mathrm{g}$ of total RNA using NEXscript cDNA synthesis kit (NEX Diagnostics, Korea) according to the manufacturer's protocols. Primers for target genes MMP9, TNF- $\alpha$, IL$1 \beta$, IL-4, G-CSF, NF-kB and house-keeping gene $\beta$-actin were listed in Table 2. Evaluation of primer efficiency and expression of the targeted genes were performed using NEXpro qPCR
Evagreen Master Mix (NEX Diagnostics, Korea) using Eco Real Time PCR system (Illumina, USA) by the following steps: $95{ }^{\circ} \mathrm{C}$ for $2 \mathrm{~min}, 40$ cycles of $95{ }^{\circ} \mathrm{C}$ for $10 \mathrm{~s}, 60{ }^{\circ} \mathrm{C}$ for $45 \mathrm{~s}$ and acquisition of fluorescent signal. Expression of the targeted genes in the samples were normalized by $\beta$-actin and the fold change in the expression of each target gene was calculated by the Eco 48 Software (Illumina, USA) using the efficiency-corrected method.

\subsection{Serum IL-1 $\beta$ and TNF- $\alpha$ levels}

IL-1 $\beta$ and TNF- $\alpha$ cytokines level in the serum were measured by ELISA kits (R\&D system, USA) according to the manufacturer's protocol.

\subsection{Secondary tumor regeneration}

Tumor was harvested and dissociated using accutase (Innovative Cell Tech, USA). Mice ( $n=10,8$ weeks old) were separated into two groups. All mice were injected subcutaneously with $1 \times$ $10^{6}$ cells harvested from untreated tumor in the lower left abdomen. On the other hand, mice in group 1 and 2 were injected subcutaneously with $1 \times 10^{6}$ cells harvested from the tumor of curcumin $50 \mathrm{mg} \mathrm{kg}{ }^{-1} \mathrm{BW}$ mice and BHMC $50 \mathrm{mg} \mathrm{kg}^{-1}$ BW tumor in the lower right abdomen, respectively. Tumor progression was then observed for 21 days.

\section{Results}

\subsection{In vitro cytotoxicity of BHMC on $4 \mathrm{~T} 1$ cells}

BHMC was prepared as previously described. ${ }^{31}$ The in vitro cytotoxicity of BHMC was compared with curcumin on 4T1 cells by MTT assay. As shown in Table 1, both BHMC and curcumin were cytotoxic to $4 \mathrm{~T} 1$ cells in time dependent manner where the $\mathrm{IC}_{50}$ value of both treatment reduced from 24 to 72 hours. More interestingly, $\mathrm{IC}_{50}$ value of $\mathrm{BHMC}$ at 48 and 72 hours were approximately 2 folds lower than curcumin on $4 \mathrm{~T} 1$ cells.

\subsection{In vivo antitumor effect of BHMC on $4 \mathrm{~T} 1$ challenged mice}

To evaluate the antitumor effect of BHMC on breast cancer, mice challenged with $4 \mathrm{~T} 1$ breast cancer cells were subjected to $50 \mathrm{mg} \mathrm{kg}^{-1} \mathrm{BW}$ of curcumin or BHMC treatment. Tumor start to observe at day 5 in untreated mice post-inoculation of 4T1 cells. Both curcumin and BHMC treated mice were observed with 5 and 9 days delay of tumor formation comparing to the untreated mice (Fig. 2A). After 28 days of treatment, without changes of the body weight were observed in all the mice (Fig. 2B), tumor burden of curcumin and BHMC treated mice were 1.86 and 3.10 folds smaller than the untreated mice (Fig. 2C and D). Based on the histology analysis, tumor

Table $1 \quad \mathrm{IC}_{50}$ value $(\mu \mathrm{M})$ of $\mathrm{BHMC}$ and curcumin on murine $4 \mathrm{~T} 1$ breast cancer cells

\begin{tabular}{llll}
\hline & $24 \mathrm{~h}$ & $48 \mathrm{~h}$ & $72 \mathrm{~h}$ \\
\hline BHMC $(\mu \mathrm{M})$ & $54.64 \pm 2.33$ & $21.66 \pm 2.66$ & $13.66 \pm 3.24$ \\
Curcumin $(\mu \mathrm{M})$ & $81.44 \pm 2.44$ & $48.86 \pm 3.46$ & $27.15 \pm 2.36$
\end{tabular}



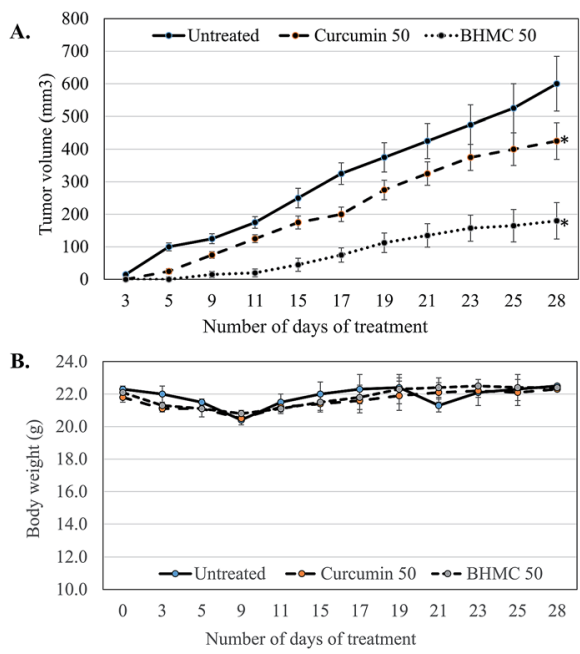

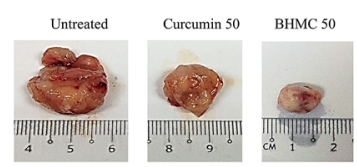

D.

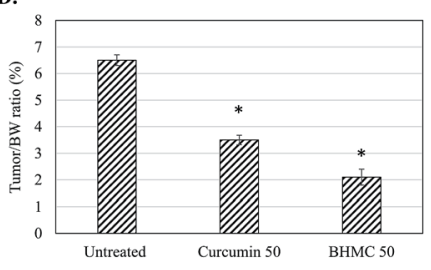

Fig. 2 (A) Tumor volume change; (B) body weight change; (C) representative image of tumor harvested (D) tumor/BW ratio of untreated, curcumin $50 \mathrm{mg} \mathrm{kg}^{-1}$ BW mice and BHMC $50 \mathrm{mg} \mathrm{kg}^{-1}$ BW $4 \mathrm{~T} 1$ challenged mice. Significant values were calculated against untreated group $(* P<$ 0.05).

harvested from untreated mice was observed with highest number mitotic cells. On the other hand, curcumin and BHMC treated mice were recorded with 1.67 and 3.75 folds less number of mitotic cells in the tumor (Fig. 3), which indicated that lower tumor burden in the curcumin and BHMC treated mice maybe contributed by anti-proliferation effect. In addition, clonogenic assay has shown that high number of $4 \mathrm{~T} 1$ breast cancer cells have metastasized to lung in the untreated mice. On the other hand, mice treated with curcumin and BHMC were observed with lower event of 4T1 metastasis into lung indicating that both treatment possess anti-metastasis effect (Fig. 4). Overall, antitumor effect of BHMC was better comparing to curcumin as the BHMC treated mice was recorded with lower tumor burden (Fig. 2), mitotic cells in the tumor (Fig. 3) and lung metastasis (Fig. 4) comparing to the curcumin treated mice.

To understand the regulation of inflammation and metastasis related genes by both curcumin and BHMC treatment, which contribute to the delay of tumor progression, expression of MMP9, TNF- $\alpha$, IL- $1 \beta$, IL-4, G-CSF and NF-kB genes in the tumor of untreated, curcumin 50 and BHMC 50 treated mice were evaluated by RT-qPCR (Fig. 5). BHMC treatment was able to suppress expression of MMP9, TNF- $\alpha$, IL-1 $\beta$, IL-4, G-CSF and NF-kB genes comparing to the untreated mice. On the other hand, curcumin treated was able to suppress expression of TNF$\alpha$, IL-1 $\beta$, IL-4, G-CSF and NF-kB genes comparing to the untreated mice. However, expression of MMP9 was not significantly regulated by curcumin treatment (Fig. 5). Level of IL-1 $\beta$ and TNF- $\alpha$ were further validated by checking serum IL-1 $\beta$ and TNF- $\alpha$ by ELISA. Both curcumin and BHMC treatment were able to reduce the serum level of IL- $1 \beta$ and TNF- $\alpha$ comparing to the untreated mice (Fig. 6).

Furthermore, regeneration capacity of the tumor harvested from untreated and curcumin or BHMC treated mice were evaluated by transplanting 1 million cells to healthy mice. When injected with tumor cells harvested from untreated and BHMC treated $4 \mathrm{~T} 1$ challenged mice, tumor/BW ratio generated
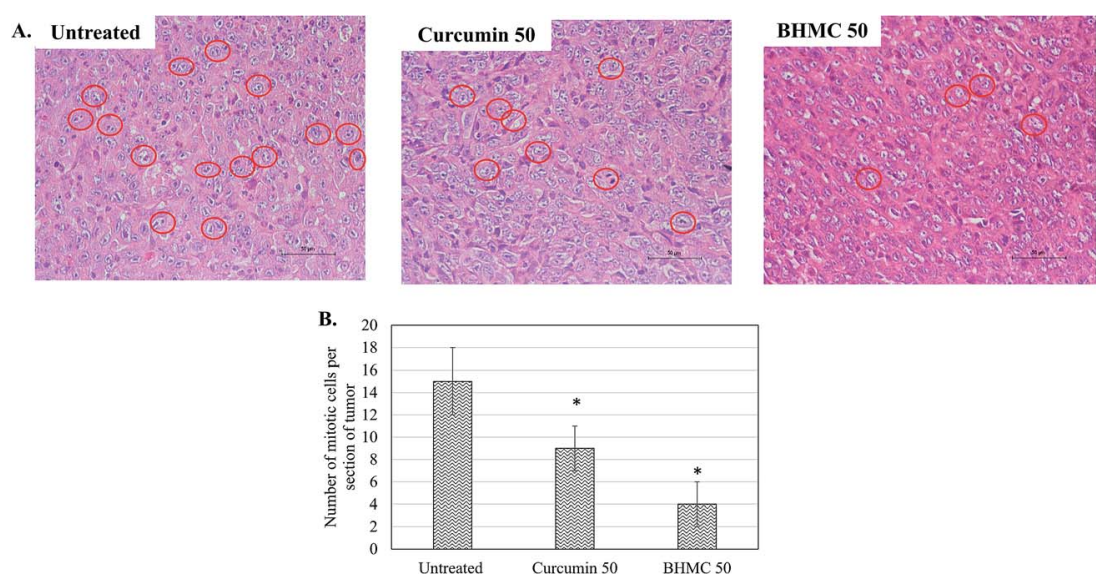

Fig. 3 (A) Histological staining of the tumor. Red circles indicate mitotic cells. (B) Numbers of mitotic cells per groups. Significant values were calculated against untreated group $(* P<0.05)$. 

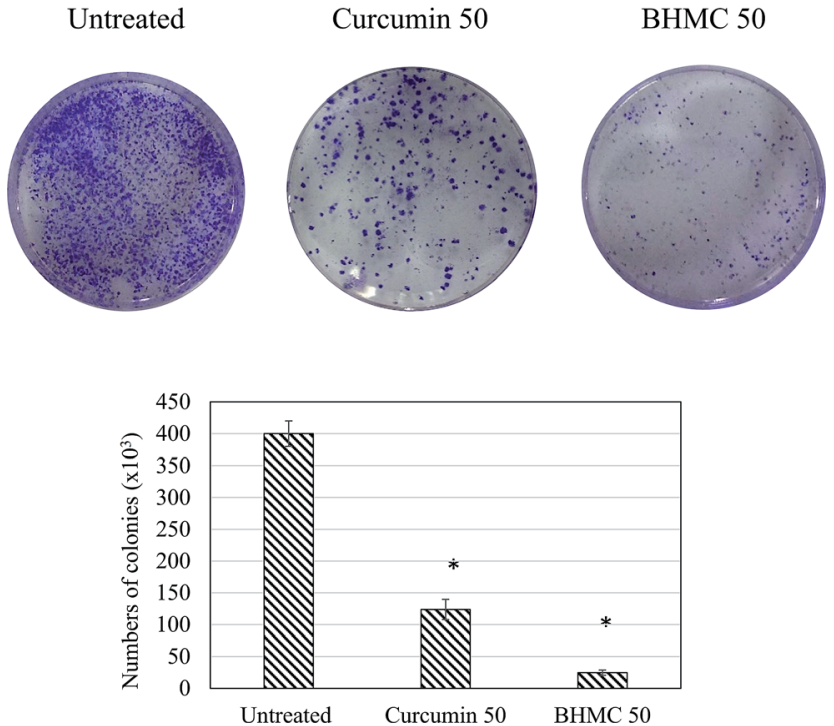

Fig. 4 RT-qPCR analysis on expression of MMP9, TNF- $\alpha, I L-1 \beta, I L-4$, G-CSF and NF-kB genes in the tumor of untreated, curcumin $50 \mathrm{mg}$ $\mathrm{kg}^{-1} \mathrm{BW}$ mice and BHMC $50 \mathrm{mg} \mathrm{kg}^{-1}$ BW $4 \mathrm{~T} 1$ challenged mice. Results were indicated in the $\beta$-actin normalized fold changes comparing to the untreated control. Fold changes $>2$ were indicated as significant.

from the untreated tumor cells was approximate 2.8 fold higher than the tumor generated from BHMC group. On the other hand, tumor generated from curcumin treated mice was only 1.25 fold lower than tumor generated from the untreated mice (Fig. 7).

\section{Discussion}

Prognosis of TNBC remains poor in spite of advance in understanding of breast cancer pathologic features and molecular characteristics. ${ }^{37}$ TNBC are more difficult to treat as they carry fewer targets and generally develop resistant to conventional chemotherapeutic agents. $^{38}$ Thus, there is a need to continue the discovery of novel effective cytotoxic agents against TNBC with minimum or no toxic side effect. Curcumin is a polyphenol presents in the turmeric Curcumina longa. It belongs to the 1,3-

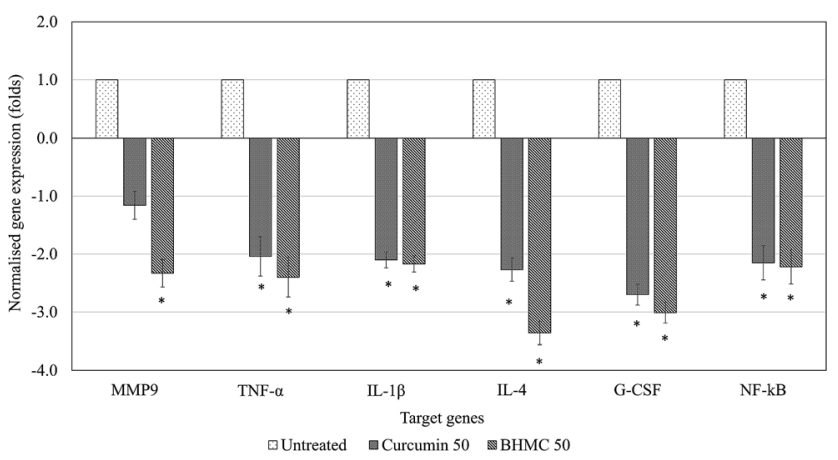

Fig. 5 Serum IL-1 $\beta$ and TNF- $\alpha$ level of untreated, curcumin $50 \mathrm{mg}$ $\mathrm{kg}^{-1}$ BW mice and BHMC $50 \mathrm{mg} \mathrm{kg}^{-1}$ BW $4 \mathrm{~T} 1$ challenged mice. Significant values were calculated against untreated group $(* P<0.05)$. dicarbonyl or $\beta$-diketone class of compounds, which possess several biological activities including important building blocks for the synthesis of core heterocycles such as pyrazole, isoxazole, and triazole in medicinal chemistry. ${ }^{39}$ Curcumin has been identified as strong anti-inflammatory agents that has broad spectrum of antitumor activity. ${ }^{35}$ Structure activity relationship of curcumin and its analogous is well established in the literatures. ${ }^{\mathbf{4 0 , 4 1}}$ Curcumin was reported as potential agents targeting TNBC as recent study has reported that it was more sensitive to human TNBC MDA-MB-231 cells than human estrogen dependent MCF-7 breast cancer cells. ${ }^{42} \mathrm{~A}$ part of interesting biological activities, still curcumin not recommended for therapeutic potential because of low bioavailability. ${ }^{26,27}$ Therefore, there is need to modify its structure to improve the bioavailability, stability and selectivity. Recent study further support the idea that synthetic chemistry help to enhance the efficacy and safety of known natural metabolites. ${ }^{43}$ For examples, curcumin analogues were reported with enhance cytotoxicity on various types of cancer cells. ${ }^{28,44}$ In this study, BHMC that is the analog of curcumin was synthesized. Previously, the antinociceptive activity ${ }^{31}$ and anti-inflammatory effect $^{29,30}$ of BHMC were evaluated. Unlike curcumin that contain enol moiety, BHMC possessing $\alpha, \beta$-unsaturated bisenone system which is an essential for the several biological activities including anticancer effect as in chalcones and bischalcones. ${ }^{41}$ Such compounds with conjugated enones or enone-like compounds exhibited potential interaction with Michael acceptor can react selectively with target nucleophiles. ${ }^{41}$ This structure may contributed to the greater cytotoxic effect of BHMC on $4 \mathrm{~T} 1$ cells in vitro, which was similar to the previous in vitro studies on human TBNC MDA-MB-231 cells. ${ }^{34}$

In addition, in vivo antitumor effect of BHMC was compared with curcumin using mouse 4T1 model. Mice challenged with 4T1 has been used as in vivo model to evaluate antitumor and antimetastasis effect of chemicals on TNBC. ${ }^{45,46}$ In this study, untreated mice was recorded with tumor development on day 3 post challenged. In addition, high tumor mitotic event and lung metastasis were observed too. On the other hand, both curcumin and BHMC treatment were found with delayed tumor formation. Curcumin was reported to suppress cell

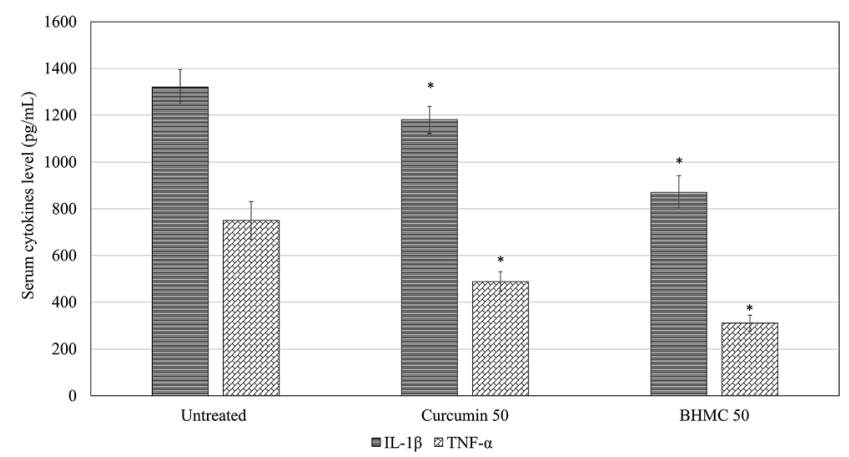

Fig. 6 Representative images and bar chart of the colonies formed in lung of untreated, curcumin $50 \mathrm{mg} \mathrm{kg}^{-1}$ BW mice and BHMC $50 \mathrm{mg}$ $\mathrm{kg}^{-1}$ BW 4T1 challenged mice. Significant values were calculated against untreated group $(* P<0.05)$. 
Untreated Curcumin 50
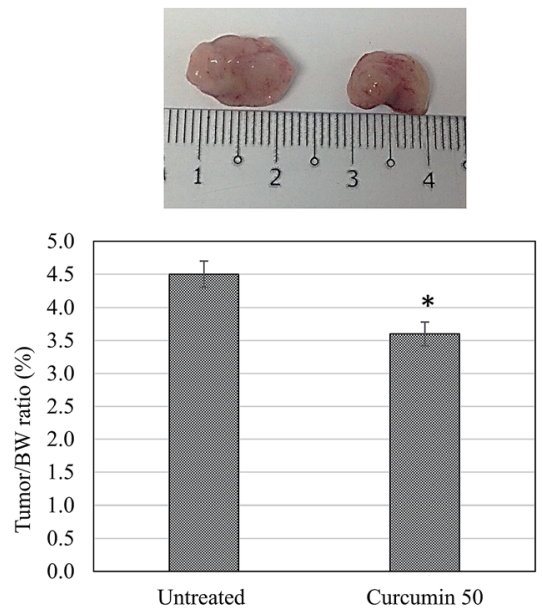

Untreated BHMC 50
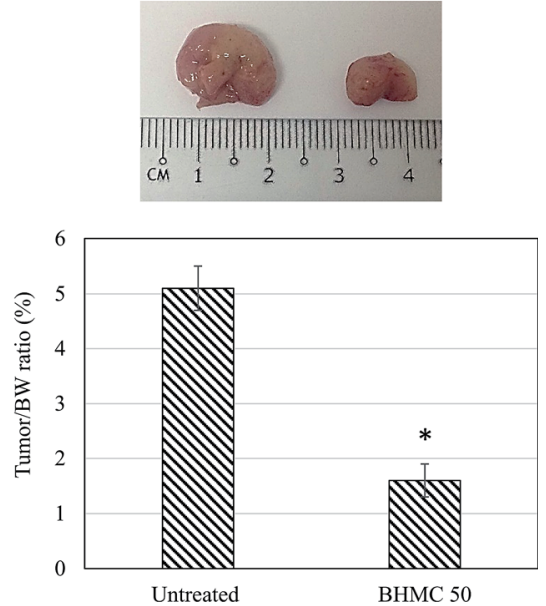

Fig. 7 Tumor/BW ratio of mice transplanted with $1 \times 10^{6}$ cells harvested from untreated tumor in the lower left abdomen and $1 \times 10^{6}$ cells harvested from curcumin $50 \mathrm{mg} \mathrm{kg}^{-1} \mathrm{BW}$ mice or BHMC $50 \mathrm{mg} \mathrm{kg}^{-1} \mathrm{BW}$ tumor in the lower right abdomen. Significant values were calculated against untreated group $(* P<0.05)$.

Table 2 Primer sequences for qRT-PCR gene expression study

Primer sequence $\left(5^{\prime}-3^{\prime}\right)$

\begin{tabular}{lll} 
Gene & Forward & Reverse \\
\hline MMP9 & GTCTTCCTGGGCAAGCAGTA & CTGGACAGAAACCCCACTTC \\
TNF- $\alpha$ & CATCTTCTCAAAATTCGAGTGACAA & TGGGAGTAGACAAGGTACAACCC \\
IL-1 $\beta$ & CGCCAATGACTCAGAGGAAGA & AGGGCGTCATTCAGGATGAA \\
IL-4 & AGATGGATGTGCCAAACGTCCTCA & AATATGCGAAGCACCTTGGAAGCC \\
G-CSF & CTCAGAAATGTTGACCTCCAG & TGACAAGCAGAAAGTCCTTCAG \\
NF-kB & GTG CGTCTGGCCTGGTAAG & CCCAGGATGTG TACTCAGAGC \\
$\beta-$ Actin & TCCTTCCTGGGCATGGAG & AGGAGGAGCAATGATCTTGATCTT
\end{tabular}

proliferation of TNBC in vitro. ${ }^{47}$ Lower number of mitotic cells observed in the tumor of curcumin and BHMC treated mice supported the report on the in vitro antiproliferation effect and given the idea that lower tumor burden in the treated mice maybe contributed by the inhibition of $4 \mathrm{~T} 1$ cells proliferation. The antiproliferative effect of BHMC has been correlated to its interactions with nuclear type II sites. ${ }^{33}$

TNBC is a type of highly metastatic cancer. ${ }^{48}$ Inflammation was found to promote tumor cell proliferation and expression of MMP9 that support the cancer metastasis. ${ }^{49}$ Curcumin has been reported with in vitro antimetastatic effect on breast cancer via suppression of MMP-9 (ref. 50) and suppression of inflammation. ${ }^{51}$ In this study, both curcumin and BHMC were found with lower lung metastasis comparing to untreated mice. This antimetastatic effect maybe contributed by the suppression of inflammatory and MMP9 as observed in the gene expression study. Although both curcumin and BHMC show similar inhibition on inflammatory related genes, significant suppression of MMP9 expression by BHMC may contribute to its better antimetastatic effect than curcumin. Previous study has shown that curcumin possessed substantial antitumor and antimetastasis when treated at $800 \mathrm{mg} \mathrm{kg}{ }^{-1} \mathrm{BW} \cdot{ }^{35}$ Encapsulation of curcumin with dendrosome help to reduce the effective dosage to $40 \mathrm{mg} \mathrm{kg}{ }^{-1} \mathrm{BW}^{52}$ In addition, TNBC was also known with high rate of recurrence. ${ }^{48}$ In this study, recurrence of untreated tumor with tumor harvested from curcumin or BHMC treatment were compared by injected them in the secondary healthy mice. After 21 days of secondary challenge, tumor burden originated from BHMC treated mice were remain lowest comparing those from untreated or curcumin treated mice. This result indicate that BHMC may even help to delay recurrence of TNBC even better than curcumin.

\section{Conclusions}

This study reported that the synthesis BHMC, which is an analogue of curcumin showed better in vitro cytotoxicity and in vivo antitumor effect on $4 \mathrm{~T} 1 \mathrm{TNBC}$ model than curcumin via suppression of inflammation, cancer cells proliferation and metastasis.

\section{Conflict of interest}

All authors in this article declare no conflict of interest. 


\section{Acknowledgements}

This study was supported by Universiti Malaysia Pahang (internal grant no. RDU 150109 and 150349), MARDI internal grant (vote no. 6300300) and MAKNA cancer research award 2013 (vote no. 6300123).

\section{References}

1 C. Fitzmaurice, C. Allen, R. M. Barber, L. Barregard, Z. A. Bhutta, H. Brenner, et al., JAMA Oncol., 2015, 1, 505-527. 2 F. Andre and C. C. Zielinski, Ann. Oncol., 2012, 23, vi46-vi51. 3 M. T. Cook, Y. Liang, C. Besch-Williford and S. M. Hyder, Breast Cancer, 2016, 9, 9-19.

4 P. Thulasiraman, D. J. McAndrews and I. Q. Mohiudddin, BMC Cancer, 2014, 14, 724.

5 X. D. Sun, X. E. Liu and D. S. Huang, Mol. Med. Rep., 2012, 6, 1267-1270.

6 S. Neidle and D. E. Thurston, Nat. Rev. Cancer, 2005, 5, 285296.

7 A. L. Demain and P. Vaishnav, Microb. Biotechnol., 2011, 4, 687-699.

8 S. C. Gupta, S. Patchva, W. Koh and B. B. Aggarwal, Clin. Exp. Pharmacol. Physiol., 2012, 39, 283-299.

9 B. B. Aggarwal, A. Kumar and A. C. Bharti, Anticancer Res., 2003, 23, 363-398.

10 O. P. Sharma, Biochem. Pharmacol., 1976, 25(15), 1811-1812.

11 A. J. Ruby, G. Kuttan, K. D. Babu, K. N. Rajasekharan and R. Kuttan, Cancer Lett., 1995, 94, 79-83.

12 Y. Sugiyama, S. Kawakishi and T. Osawa, Biochem. Pharmacol., 1996, 52, 519-525.

13 R. C. Srimal and B. N. Dhawan, J. Pharm. Pharmacol., 1973, 25, 447-452.

14 W. C. Jordan and C. R. Drew, J. Natl. Med. Assoc., 1996, 88, 333.

15 M. K. Kim, G. J. Choi and H. S. Lee, J. Agric. Food Chem., 2003, 51, 1578-1581.

16 R. C. Reddy, P. G. Vatsala, V. G. Keshamouni, G. Padmanaban and P. N. Rangarajan, Biochem. Biophys. Res. Commun., 2005, 326(2), 472-474.

17 R. Kuttan, P. Bhanumathy, K. Nirmala and M. C. George, Cancer Lett., 1985, 29(2), 197-202.

18 X. Zhang, Y. Tian, Z. Li, X. Tian, H. Sun, H. Liu, A. Moore and C. Ran, J. Am. Chem. Soc., 2013, 135, 16397-16409.

19 Y. Kiso, Y. Suzuki, N. Watanabe, Y. Oshima and H. Hikino, Planta Med., 1983, 49, 185-187.

20 N. Venkatesan, Br. J. Pharmacol., 1998, 124, 425-427.

21 N. Venkatesan, D. Punithavathi and V. Arumugam, Br. J. Pharmacol., 2000, 129, 231-234.

22 R. Srivastava, M. Dikshit, R. C. Srimal and B. N. Dhawan, Thromb. Res., 1985, 40, 413-417.

23 M. Dikshit, L. Rastogi, R. Shukla and R. C. Srimal, Indian J. Med. Res., 1995, 101, 31-35.

24 C. Nirmala and R. Puvanakrishnan, Mol. Cell. Biochem., 1996, 159, 85-93.

25 C. Nirmala and R. Puvanakrishnan, Biochem. Pharmacol., 1996, 51, 47-51.
26 K. M. Nelson, J. L. Dahlin, J. Bisson, J. Graham, G. F. Pauli and M. A. Walters, J. Med. Chem., 2017, 60, 1620-1637.

27 K. M. Nelson, J. L. Dahlin, J. Bisson, J. Graham, G. F. Paulin and M. A. Walters, ACS Med. Chem. Lett., 2017, 8, 467-470.

28 C. D. Mock, B. C. Jordan and C. Selvam, RSC Adv., 2015, 5, 75575-75588.

29 C. L. Tham, C. Y. Liew, K. W. Lam, A. S. Mohamad, M. K. Kim, Y. K. Cheah, Z. A. Zakaria, M. R. Sulaiman, N. H. Lajis and D. A. Israf, Eur. J. Pharmacol., 2010, 628, 247-254.

30 C. L. Tham, K. W. Lam, R. Rajajendram, Y. K. Cheah, M. R. Sulaiman, N. H. Lajis, M. K. Kim and D. A. Israf, Eur. J. Pharmacol., 2011, 652, 136-144.

31 L. Ming-Tatt, S. I. Khalivulla, M. N. Akhtar, A. S. Mohamad, E. K. Perimal, M. H. Khalid, A. Akira, N. Lajis, D. S. Israf and M. R. Sulaiman, Basic Clin. Pharmacol. Toxicol., 2012, 110, 275-282.

32 D. Lv, Y. Zhang, H. J. Kim, L. Zhang and X. Ma, Cell. Mol. Immunol., 2013, 10, 303-310.

33 B. M. Markaverich, T. H. Schauweker, R. R. Gregory, M. Varma, F. S. Kittrell, D. Medina and R. S. Varma, Cancer Res., 1992, 52, 2482-2488.

34 B. Yadav, S. Taurin, R. J. Rosengren, M. Schumacher, M. Diederich, T. J. Somers-Edgar and L. Larsen, Bioorg. Med. Chem. Lett., 2010, 18, 6701-6707.

35 M. Singh, I. Ramos, D. Asafu-Adjei, W. Quispe-Tintaya, D. Chandra, A. Jahangir, X. Zang, B. B. Aggarwal and C. Gravekamp, Cancer Med., 2013, 2, 571-582.

36 A. S. Mohamad, M. N. Akhtar, S. I. Khalivulla, E. K. Perimal, M. H. Khalid, H. M. Ong, S. Zareen, A. Akira, D. A. Israfl, N. Lajis and M. R. Sulaiman, Basic Clin. Pharmacol. Toxicol., 2011, 108, 400-405.

37 M. Arnedos, C. Bihan, S. Delaloge and F. Andre, Ther. Adv. Med. Oncol., 2012, 4, 195-210.

38 W. Wang, E. R. Rayburn, S. E. Velu, D. Chen, D. H. Nadkarni, S. Murugesan, D. Chen and R. Zhang, Breast Cancer Res. Treat., 2010, 123, 321-331.

39 J. Pradhan and A. Goyal, Int. J. Biol., Pharm. Allied Sci., 2015, 4, 1-18.

40 H. Yang, Z. Du, W. Wang, M. Song, K. Sanidad, E. Sukamtoh, J. Zheng, L. Tian, H. Xian, Z. Liu and G. Zhang, J. Agric. Food Chem., 2017, 65, 4509-4515.

41 M. Nakhjiri, M. Safavi, E. Alipour, S. Emami, A. F. Atash, M. Jafari-Zavareh, S. K. Ardestani, M. Khoshneviszadeh, A. Foroumadi and A. Shafiee, Eur. J. Med. Chem., 2012, 50, 113-123.

42 T. Jia, L. Zhang, Y. Duan, M. Zhang, G. Wang, J. Zhang and Z. Zhao, Cancer Cell Int., 2014, 14, 126.

43 D. A. Dias, S. Urban and U. Roessner, Metabolites, 2012, 2, 303-336.

44 N. M. Ali, S. K. Yeap, N. Abu, K. L. Lim, H. Ky, A. Z. M. Pauzi, W. Y. Ho, S. W. Tan, H. K. Alan-Ong, S. Zareen, N. B. Alitheen and M. N. Akhtar, Cancer Cell Int., 2017, 17, 30.

45 G. Ferrari-Amorotti, C. Chiodoni, F. Shen, S. Cattelani, A. R. Soliera, G. Manzotti, G. Grisendi, M. Dominici, F. Rivasi, M. P. Colombo, A. Fatatis and B. Calabretta, Neoplasia, 2014, 16, 1047-1058. 
46 P. Kaur, G. M. Nagaraja, H. Zheng, D. Gizachew, M. Galukande, S. Krishnan and A. Asea, BMC Cancer, 2012, $12,120$.

47 X. D. Sun, X. E. Liu and D. S. Huang, Mol. Med. Rep., 2012, 6, 1267-1270.

48 J. Qiu, X. Xue, C. Hu, H. Xu, D. Kou, R. Li and M. Li, J. Cancer, 2016, 7, 167-173.

49 L. Gan, Z. Qiu, J. Huang, Y. Li, H. Huang, T. Xiang, J. Wan, T. Hui, Y. Lin, H. Li and G. Ren, Int. J. Biol. Sci., 2016, 12, 1533-1543.
50 J. M. Kim, E. M. Noh, K. B. Kwon, J. S. Kim, Y. O. You, J. K. Hwang, B. M. Hwang, B. S. Kim, S. H. Lee, S. J. Lee, S. H. Jung, H. J. Youn and Y. R. Lee, Phytomedicine, 2012, 19, 1085-1092.

51 T. L. Chiu and C. C. Su, Int. J. Mol. Med., 2009, 23, 469-475. 52 B. Farhangi, A. M. Alizadeh, H. Khodayari, S. Khodayari, M. J. Dehghan, V. Khori, A. Heidarzadeh, M. Khaniki, M. Sadeghiezadeh and F. Najafi, Eur. J. Pharmacol., 2015, 758, 188-196. 